\title{
Regional higher education systems and sustainable regional economic development: functional approach
}

\author{
Elena Ogurtsova \\ Faculty of Economics \\ Saratov State University \\ Saratov, Russia \\ tirolmen@yandex.ru
}

\author{
Anna Firsova \\ Faculty of Economics \\ Saratov State University \\ Saratov, Russia \\ a.firsova@rambler.ru
}

\author{
Olga Chelnokova \\ Faculty of Economics \\ Saratov State University \\ Saratov, Russia \\ o.chelnokova@mail.ru
}

\begin{abstract}
Sustainable and competitive regional development as a response to global challenges is significantly determined by quality of workforce and reginal educational system. The aim of this research is to develop the methodology for quantitative assessment of functioning efficiency and implementation of regional higher education systems basing on the functional approach. This study allows to assess functional dynamics, structure and implementation volume of basic functions of regional higher education systems. Comparison between the results obtained in various regions of the Russian Federation demonstrates high levels of differentiation and polarization of basic functions implementation and enables to draw conclusions concerning the balance of regional higher education systems and their correlation with regional economic system development.
\end{abstract}

Keywords- regional development, economic growth, regional higher education system, efficiency

\section{INTRODUCTION}

Sustainable and competitive regional development as a response to global challenges is significantly determined by the quality of workforce, primarily, the regional higher education system.

The contribution of higher education to personnel training, knowledge generation, innovation diffusion, formation of new technological waves and socioeconomic development is considered to be a new significant factor of economic growth on regional and national levels in many countries [1].

This is why much attention is paid globally to the functioning of higher education, which is becoming one of the main sources of productivity increase and, consequently, economic growth. The latest tendencies for globalization, post-industrialization, softization, servitization, financialization and informatization of global economy determine the necessity for a human resources formation analysis in order to develop regional and national economies in the long-term perspective and establish the volume of investments to education, which have a higher efficiency level and enable to achieve high-tech competitive economy [2].

In economic researches of the last 20 years it has become axiomatic that the efficiency of educational system influences the regional economy efficiency and economic growth. According to OECD statistic survey, the higher national educational level is, the higher are the GDP and indicators of economic growth, life expectancy and health level. An increase of 1 year in average education period results in an increase of $3-6 \%$ in the GDP and of $7 \%$ in personal income. An increase of $1 \%$ in state education funding results in an increase of $0.35 \%$ of the GDP and the sum of tax revenues from the population with higher education (subtracting state educational expenses) is three times bigger than the sum of state expenses per student [3]. Mutual relation and dependency of regional economic growth and regional higher education system efficiency require the mechanisms for their balanced and congruent development taking into account regional demands.

The growing influence of education on regional economic behavior determines the relevance of research assessing congruence and efficiency of higher education development in regional economies in order to provide an objective assessment of regional development, design the tools for quantitative efficiency measurement and set the directions for state influence and reformation of higher education system.

The complex character of federal governance of the Russian Federation, territorial extent, heterogeneity of regional economic development and historically determined territorial positioning of industrial, scientific and educational 
centers result in differentiation of quality and economic growth structure in Russia.

In order to address modern challenges, for the last decades Russian higher education system has been undergoing deep structural reforms. In 2017, it was comprised of 769 higher education institutions and 692 branches in 85 Russian regions. The total volume of federal budgets funds allocated for developing leading Russian universities in 2007-2015 comprised 110 billion rubles. Due to the large-scale character and strategic importance of higher education, theoretical and methodological aspects of assessing regional higher education systems efficiency are of utmost relevance during the process of higher education system reformation.

Under these conditions, the research of fundamental aspects of regional higher education system functioning, the reasoning of Russian education system reformation conditions and directions, the modeling of regional higher education systems balanced development according to regional economy specific demands and the design of mechanisms for increasing interaction efficiency of the main regional economic system subjects become relevant scientific objectives.

The aim of the research is to develop the methodology enabling quantitative assessment of functioning efficiency and implementation of basic functions by reginal higher education systems, basing on the functional approach.

In order to achieve its aim, this study solves tasks related to defining the theoretical research model, reasoning relevant indicators of basic functions fulfillment by education systems, collecting and processing empirical data for analyzing and testing basing on results obtained from Russian regions.

\section{MODEL}

\section{A. Research methodology}

Modern researchers outline that under globalization conditions, national economic competitiveness is determined by dynamics of regional innovation and education systems and by efficiency of interaction between their subjects, among which regional higher education systems are becoming a significant innovational growth driver [4], [5].

The regional higher education system is viewed as the total number of state and private higher education institutions functioning in the region (Federal subject) and the interaction between them, subjects and stakeholders in the regional economy.

The efficiency of regional higher education system functioning and the synergetic effect of subjects' interaction in the regional economic system through targeted provision of workforce for regional demands have an impact on economic growth and regional development, while strengthening of cooperative relations creates the basis for enlivening regional economy and sustainable economic growth [6]. Determining mechanisms for assessing and strengthening these relations using the functional approach is a relevant task that still requires solution.

During the last decades significant changes have been made to the interaction between universities and regional innovation system subjects. Alongside with traditional educational (human resources training), exploratory (generation of new knowledge and technologies) and integrational (productive interaction of graduates within the professional community) functions of universities, new functions have become institutionalized (social mission and partnership in regional development, interaction between universities and local communities, knowledge integration and transfer, entrepreneurship and creation of new activities, businesses, innovational infrastructure) [7], [8], [9].

Application of structural-functional analysis enables to study regional higher education systems as the key element of regional economic system that provides its extensive reproduction by performing scientific, educational and social functions.

The implementation of the abovementioned functions within the framework of regional socioeconomic system demonstrates the functional dependency between regional higher education system and various regional economic subsystems - the functional determinism, which acts as the cause for development of this system. Scientific, educational and social functions of regional higher education system characterize the integral attributes of this system and its elements - educational institutions of various specializations. The integral attributes of the system can be demonstrated by a certain impact of systematic education on the economy.

In case of congruent interaction between all elements of regional higher education system and regional economic subsystems all functions are implemented to their full extent, thus demonstrating the integrity-focused interaction between system elements, between the system and the external environment and other systems providing its sustainable development.

Despite multiple approaches, concepts, ratings, methods and indicators, current Russian practice has no common methodology, tools and assessment system, which could be applied to studying balanced higher education development, thus leaving this aspect open for discussion within the scientific community. This study continues the search for methods and tools for quantitative efficiency assessment of regional higher education systems.

\section{B. Research data}

According to the abovementioned approaches to studying the role and functions of modern universities in relation to regional development, this research analyzes indicators characterizing activity of Russian regional higher education systems of 830 institutions from 80 Russian regions, dated 2016, as represented by Figure 1.

The efficiency of regional higher education system within this approach is based on its functioning results demonstrated by the number of students and course participants, efficiency of research and scientific works, the volume of scientific publications and intellectual activity results, as well as the number of regional economy partnerships providing economic effect. 
Russian practice of statistical observation shows no evidence of collecting such higher education activity indicators. This issue complicates the process of assessing efficiency of regional higher education systems. As the source materials for this research, we have used Informational and analytical data taken during the monitoring of higher education institutions efficiency by Russian Ministry of Education and Science, as well as the information from Federal State Statistics Service Central Base of Statistical Data [10], [11].

Judging from the analysis of basic universities functions, the indicators characterizing regional higher education system functioning have been divided into 3 groups according to the number of basic functions, in order to trace the representation of each function:

\section{EDUCATION}

The number of bachelor's degree, master's degree and specialist's degree students

The number of additional professional education courses participants

\section{SCIENCE}

The number of faculty personnel and scientific workers

The number of postgraduate students, interns, assistants, doctoral candidates

The number of higher education organizations publications calculated per 100 scientific and pedagogical workers

The number of legally protected intellectual activity results

\section{PARTENRSHIPS}

The number of business incubators, science parks and centers for scientific equipment collective use

The number of higher education organizations small enterprises

The number of enterprises with contractual relations for specialist training

The number of enterprises with contractual relations for work placement provision

Fig. 1.Indicators of regional higher education institutions basic functions implementation.

- the results of implementing educational functions are represented by the total number of bachelor's degree, master's degree and specialist's degree students, as well as the number of additional professional education courses participants;

- exploratory function and scientific research generation are represented by the number of workers involved in research activities and by quantitatively measurable research results (publications and patents);

- social function demonstrates the interaction between innovation system actors, innovation system, partners, ability to produce new knowledge throughout educational and exploratory activities, create and gather intellectual resources required for implementing innovational activity and conditions for spreading research results and development of scientific and informational relations in the region. The congruence of these relations has a positive influence on regional economy.

These indicators have been collected separately for each educational institution and then aggregated according to regions making a characteristic of higher education systems of Russian Federation subjects, thus creating a sampling covering 80 regions. Moscow, Moscow Oblast, Saint Petersburg, the Crimea, Sevastopol and Chukotka have been excluded from the analysis due to high polarization of indicators distorting the chart representation of the model.

In order to compare the indicators for analysis, they have been normalized using linear scaling method and aggregated within each group. Thus, we have obtained the quantitative assessment of regional higher education systems basic function implementation parameters.

\section{RESULTS AND DISCUSSION}

As a result of the abovementioned method application, we have obtained the following characteristics of regional higher education institutions basic functions fulfilment in crossregional section, as represented in Figure 2. The regional indicators have been ranged in the decreasing order of their educational function.

Our research enables to assess the functional dynamics, structure and volume of regional higher education institutions basic functions implementation. The comparison between Russian federation regions demonstrates a high level of differentiation and polarization in basic functions implementation and enables to draw conclusions concerning the balance of regional higher education systems and their correlation with regional economic system development. In particular, we have come to the following conclusion:

- the leading regions basing on the number of students and educational function volume (Tatarstan, Sverdlovsk Oblast, Samara Oblast, Nizhny Novgorod Oblast, Krasnodar Krai, Rostov Oblast and others) are the centers for economic and intellectual development and are characterized by high innovational activity, well-established interaction between regional economic system participants and cooperation with universities and have well-balanced proportions of regional higher education system basic functions implementation; 


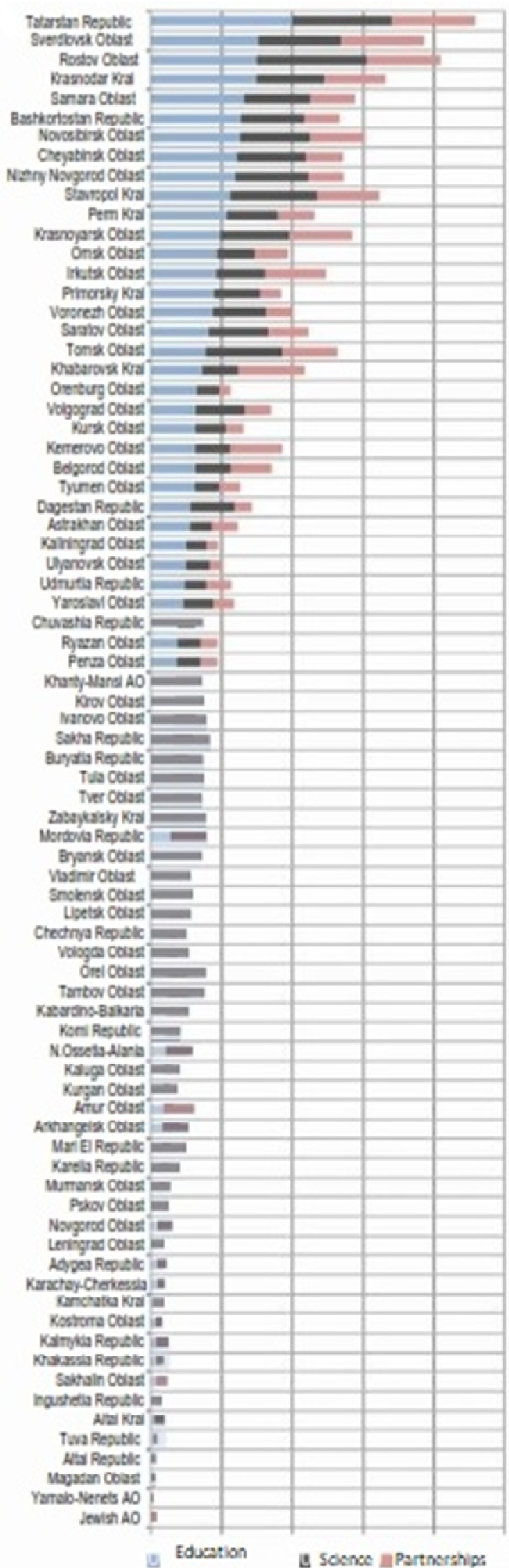

Fig. 2. Implementation of regional higher education systems functions
- the region with low economic development level and low innovational potential (e.g. Orenburg Oblast, the Chuvash Republic, Vladimir Oblast) are characterized by an imbalanced structure of regional higher education systems basic functions, with underdeveloped scientific and (especially) regional partnership functions. Despite the potential of regional higher education systems, these regions lack the opportunities for its application, resulting in nonfulfillment of this potential and inefficiency of regional economic systems.

The suggested approach could be applied as an analytical tool for analyzing, assessing, ranging and differentiating the structures of regions and regional higher education systems from the viewpoint of their efficiency and development balance.

\section{CONCLUSION}

Thus, this research provides approaches to assessment of the basic university functions implementation in Russian regions, enabling to perform a quantitative assessment of functional dynamics and structure of regional higher education system through their fulfillment of three functions (educational, scientific and regional partnership) in relation to regional economic development indicators.

This approach provides a multifaceted and objective representation of regional higher education systems efficiency and structure, expanding regional development assessment tools.

The research results may be applied for solving tasks concerning institutional management improvement during reform planning and regional higher education systems transformation.

The practical value of this approach to regional higher education systems basic functions implementation is in its opportunity for application in developing mechanisms for education efficiency improvement and regional higher education systems efficiency assessment.

\section{Acknowledgment}

The reported study was supported by Russian Foundation for Basic Research, project "Development of methodology and tools for assessing the effectiveness of regional higher education system and modelling its balanced development", № 18-010-01115

\section{References}

[1] Chl. J. Haynes, "Education and Economic Development", ERIC Digest Series, 2010, 23, 5 .

[2] T. Kartushina, A, Firsova, "The commercialization of optical techniques in Russian regions: experience and problems," Proc. SPIE 5771, 2004: Optical Technologies in Biophysics and Medicine VI, http: doi: $10.1117 / 12.634865$

[3] Education at a Glance, 2010 OECD indicators. URL: http://www.uis.unesco.org/Education/Documents/45926093.pdf

[4] J. B. Goddard, P. Chatterton, "The response of universities to regional needs," European Journal of Education, 2002, Vol. 35(4), pp. 475-496.

[5] A. Jaffe, "Real effects of academic research," American Economic Review, 1989, Vol. 79, pp. 957-970. 
[6] H., Etzkowitz, L. Leydesdorff, "The triple helix - university - industry government relations : a laboratory for knowledge-based economic development," EASST Review, 1995, 14(1), 14-19.

[7] P. Arbo, P. Benneworth, "Understanding the regional contribution of higher education institutions: a literature review," OECD Education Working Paper, 2007, pp. 9.

[8] W. Schweke, "Smart Money: Education and Economic Development," Economic Policy Institute, 2004, pp. 74.

[9] Th. Estermann, E. B. Pruvot and A.-L. Claeys-Kulik, "Designing strategies for efficient funding of higher education in Europe", EUA, 2013, 20 p.
[10] Information and analytical materials on the results of monitoring the effectiveness of educational institutions of higher education. Ministry of Education and Science of the Russian Federation [Informatsionnoanaliticheskie materialy po rezul'tatam provedeniia monitoringa effektivnosti deiatel'nosti obrazovatel'nykh organizatsii vysshego obrazovaniia. Ministerstvo obrazovaniia i nauki Rossiiskoi Federatsii], URL: http://indicators.miccedu.com/monitoring/?m=vpo.

[11] The Russian Federal Service of State Statistics [Rosstat]. URL http://www.gks.ru/wps/wcm/connect/rosstat_main/rosstat/en/statistics/sc ience_and_innovations/science/\# 